\title{
A new species of Notogynaphallia (Platyhelminthes, Geoplanidae) extends the known distribution of land planarians in Chacoan province (Chacoan subregion), South America
}

\author{
Lisandro Negrete ${ }^{1,2}$, Ana Maria Leal-Zanchet ${ }^{3}$ and Francisco Brusa ${ }^{1,2^{*}}$
}

\begin{abstract}
Background: The subfamily Geoplaninae (Geoplanidae) includes land planarian species of the Neotropical Region. In Argentina, the knowledge about land planarian diversity is still incipient, although this has recently increased mainly in the Atlantic Forest ecosystem. However, other regions like Chacoan forests remain virtually unexplored.

Results: In this paper, we describe a new species of the genus Notogynaphallia of the Chacoan subregion. This species is characterized by a black pigmentation on the dorsum and a dark grey ventral surface. The eyes with clear halos extend to the dorsal surface. The pharynx is cylindrical. The main features of the reproductive system involve testes anterior to the ovaries, prostatic vesicle intrabulbar (with a tubular proximal portion and a globose distal portion) opening broadly in a richly folded male atrium, common glandular ovovitelline duct and female genital canal dorso-anteriorly flexed constituting a " $\mathrm{C}$ ", female atrium tubular proximally and widening distally.

Conclusions: This is the first report of the genus Notogynaphallia in Argentina (Chacoan subregion, Neotropical Region) which increases its geographic distribution in South America. Also, as a consequence of features observed in species of the genus, we propose an emendation of the generic diagnosis.
\end{abstract}

Keywords: Land flatworms; Notogynaphallia; Geoplaninae; Argentina; Chacoan subregion; Neotropical Region

\section{Background}

Land planarians are free-living flatworms that live in humid environments. They cannot endure desiccation since they have not developed mechanisms for water conservation (Kawaguti 1932). Therefore, they hide from the sunlight (under fallen logs and leaf litter) and exhibit greater activity at night, predating on soil invertebrates such as earthworms, snails, slugs, insects and arachnids (Negrete et al. 2014a; Prasniski and Leal-Zanchet 2009). Due to their habitat requirements and position in the food

\footnotetext{
* Correspondence: fbrusa@fcnym.unlp.edu.ar

'División Zoología Invertebrados, Facultad de Ciencias Naturales y Museo, Universidad Nacional de La Plata, Boulevard 120 and 61, La Plata, Argentina Instituto de Pesquisas de Planárias, Universidade do Vale do Rio dos Sinos, 93022-000 São Leopoldo, Rio Grande do Sul, Brazil

Full list of author information is available at the end of the article
}

chain, land planarians are good indicator taxa in biodiversity and conservation studies (Sluys 1998).

The genus Notogynaphallia Ogren \& Kawakatsu, 1990 , as originally proposed, included 23 species which could clearly be distinguished in at least two groups (Leal-Zanchet and Froehlich 2001, 2006; Froehlich and Leal-Zanchet 2003). Carbayo (2010) removed six species, which have striped dorsum, dorsal eyes and an extrabulbar prostatic vesicle to a new genus named Luteostriata Carbayo, 2010. Later, based on morphological and molecular data for some species, the genus Notogynaphallia was re-defined, including now seven species, besides four morphologically poorly known species (Notogynaphallia incertae sedis) (Carbayo et al. 2013). Species of Notogynaphallia so far have been described for Brazil (over $70 \%$ of the species) and also 
for Colombia, Panama, Paraguay and Peru (Tyler et al. 2006-2015; Carbayo et al. 2013). This genus groups Geoplaninae species of small and medium-sized body (16-70 $\mathrm{mm}$ in length), with a reproductive system that includes a dilated intrabulbar prostatic vesicle opening broadly into a richly folded male atrium, in which folds form an eversible penis. Also, the distal ascending portions of the ovovitelline ducts are arranged laterally to the posterior portion of the female atrium, joining each other behind it. Additionally, the female genital canal is dorso-anteriorly flexed, arising from the posterior region of the female atrium (Ogren and Kawakatsu 1990; Carbayo et al. 2013).

In Argentina, where the land planarian diversity is still incipiently known, there are no records of this genus. Recently, the research about land flatworms has increased, mainly in the Atlantic Forest ecosystem (Negrete and Brusa 2012; Negrete et al. 2014a, b). However, other regions, such as the Chacoan forests, remain virtually unexplored. There are few old records of land planarians in the Chacoan province (Neotropical Region) in Asunción, Paraguay (Graff 1894, 1899). Unfortunately, the original landscape has suffered changes since then, mainly by deforestation and population growth, and there are no recent records of land planarians in this region.

In this paper, we describe a new species of land planarian, which represents the first land planarian species from this ecosystem in Argentina and the first record of Notogynaphallia in this country. Also, as a result of new features observed in species of the genus, we propose an emendation of its diagnosis.

\section{Methods}

Land planarians were collected between 2007 and 2012 in native forests within La Marcela farm $\left(26^{\circ} 17^{\prime} 35^{\prime \prime} \mathrm{S}, 59^{\circ} 06^{\prime}\right.$ $67^{\prime \prime} \mathrm{W}$ ) in Formosa province, north-eastern Argentina. The ecosystem belongs to the Chacoan province, Chacoan subregion (Neotropical Region), which extends through southern Bolivia, western Paraguay, a small portion of southern Brazil and north central and eastern Argentina (Morrone 2000, 2014). It is characterized by savannahs, hallophyllous steppes and xerophyllous caducifolious forests (Morrone 2000). However, in this region, the native forests are highly fragmented and reduced to small patches due to farming. The specimens were manually collected during the day beneath fallen logs in these forest fragments. Some animals were directly fixed in $10 \%$ formaldehyde, and others were killed in boiling water and then fixed in $10 \%$ formaldehyde and conserved in $70 \%$ ethanol. Land planarians were sectioned in fragments, dehydrated in an ascending series of ethanol and embedded in Paraplast $^{\circ}$. Sagittal and transverse serial sections $(6-8 \mu \mathrm{m}$ thick) of the anterior region, transverse sections of the prepharyngeal region (6-8 $\mu \mathrm{m}$ thick) and sagittal serial sections of the pharynx and copulatory apparatus $(6-8 \mu \mathrm{m}$ thick) were performed with a microtome and stained with Masson's trichrome and haematoxylin-eosin methods (Bancroft and Gamble 2008). The cutaneous musculature height to body height ratio (cutaneous muscular index, CMI) was calculated according to Froehlich (1955a) from transverse sections at the pre-pharyngeal level, and the parenchymatic musculature height to body height ratio (parenchymatic muscular index, PMI) was also calculated at the same level according to Winsor (1983).

The type specimens were deposited in the Invertebrate Collection at Museo de La Plata (MLP), Argentina.

\section{Results}

Taxonomy

Family Geoplanidae Stimpson, 1857

Subfamily Geoplaninae Stimpson, 1857

Genus Notogynaphallia Ogren \& Kawakatsu, 1990

Emended diagnosis of Notogynaphallia

Geoplaninae of small-to-medium-sized body (16-70 mm in length); slender body with margins nearly parallel; dorsum and ventral sides slightly convex. Eyes monolobulated marginally arranged along the body, sometimes spreading dorsally. No cephalic specializations. Cutaneous musculature not insunk into parenchyma. Parenchymatic longitudinal musculature absent. Pharynx cylindrical or bellshaped. Prostatic vesicle intrabulbar, dilated, broadly communicated with the richly folded male atrium; penis papilla eversible. Ascending portion of ovovitelline ducts lateral to posterior region of the female atrium and joining each other behind it; female genital canal dorso-anteriorly flexed, arising from the posterior region of the female atrium; female atrium irregular and narrow. Adenodactyls or glandulo-muscular organs absent.

\section{Notogynaphallia nawei sp. nov. urn:Isid:zoobank.org:act:B36A4C5F-D452-4502-8AF5- 774460DCF61A \\ Type series}

Holotype: MLP-He 6807. Formosa, Argentina, 17 September 2012; anterior region 1: transverse sections on 14 slides (6-8 $\mu \mathrm{m}$ thick); anterior region 2 : sagittal sections on 32 slides ( $8 \mu \mathrm{m}$ thick); pre-pharyngeal region: transverse sections on 6 slides ( $8 \mu \mathrm{m}$ thick); pharynx and copulatory apparatus: sagittal sections on 47 slides (7 $\mu \mathrm{m}$ thick).

Paratype 1: MLP-He 6808. Formosa, Argentina, 17 September 2012; anterior region 1: transverse sections on 12 slides (6 $\mu \mathrm{m}$ thick); anterior region 2: sagittal sections on 42 slides ( $8 \mu \mathrm{m}$ thick); pre-pharyngeal region: transverse sections on 6 slides ( $8 \mu \mathrm{m}$ thick); pharynx and copulatory apparatus: sagittal sections on 56 slides (7 $\mu \mathrm{m}$ thick). 
Paratype 2: MLP-He 6808. Formosa, Argentina, 17 September 2012; anterior region: sagittal sections on 29 slides (8 $\mu \mathrm{m}$ thick); pre-pharyngeal region: transverse sections on 7 slides ( $8 \mu \mathrm{m}$ thick); pharynx and copulatory apparatus: sagittal sections on 25 slides $(6 \mu \mathrm{m}$ thick).

Paratype 3: MLP-He 6809. Formosa, Argentina, 3 October 2007; anterior region: sagittal sections on 18 slides (8 $\mu \mathrm{m}$ thick); pre-pharyngeal region: transverse sections on 8 slides ( $8 \mu \mathrm{m}$ thick); pharynx and copulatory apparatus: sagittal sections on 24 slides ( $8 \mu \mathrm{m}$ thick).

Paratype 4: MLP-He 6809. Formosa, Argentina, 3 October 2007; anterior region: sagittal sections on 18 slides (8 $\mu \mathrm{m}$ thick); pre-pharyngeal region: transverse sections on 8 slides ( $8 \mu \mathrm{m}$ thick); pharynx and copulatory apparatus: sagittal sections on 42 slides ( $8 \mu \mathrm{m}$ thick).

Paratype 5: MLP-He 6809. Formosa, Argentina, 3 October 2007; pre-pharyngeal region: transverse sections on 23 slides ( $6 \mu \mathrm{m}$ thick); pharynx and copulatory apparatus: sagittal sections on 68 slides (6 $\mu \mathrm{m}$ thick).

Paratype 6: MLP-He 6809. Formosa, Argentina, 3 October 2007; anterior region 1: transverse sections on 22 slides (6 $\mu \mathrm{m}$ thick); anterior region 2: sagittal sections on 16 slides (6 $\mu \mathrm{m}$ thick); pre-pharyngeal region: transverse sections on 21 slides (6 $\mu \mathrm{m}$ thick); pharynx and copulatory apparatus: sagittal sections on 26 slides (6 $\mu \mathrm{m}$ thick).

Paratype 7: MLP-He 6809. Formosa, Argentina, 5 October 2007; pre-pharyngeal region: transverse sections on 6 slides ( $7 \mu \mathrm{m}$ thick); pharynx and copulatory apparatus: sagittal sections on 23 slides ( $7 \mu \mathrm{m}$ thick).

Paratype 8: MLP-He 6809. Formosa, Argentina, 5 October 2007; anterior region 1: transverse sections on 16 slides (6 $\mu \mathrm{m}$ thick); anterior region 2: sagittal sections on 18 slides (6 $\mu \mathrm{m}$ thick); pre-pharyngeal region: transverse sections on 5 slides ( $6 \mu \mathrm{m}$ thick); pharynx and copulatory apparatus: sagittal sections on 18 slides ( $6 \mu \mathrm{m}$ thick).

\section{Diagnosis}

Species of Notogynaphallia with dorsal surface black and ventral surface dark grey with a thin longitudinal whitish line along the body; eyes dorsal, with clear halos; glandular margin absent; prostatic vesicle intrabulbar, with two regions: a tubular proximal portion and a globose distal portion with narrow lumen; common glandular ovovitelline duct and female genital canal constituting a " $\mathrm{C}$ "; female atrium tubular proximally and wide distally.

Type locality. La Marcela farm, Pirané Department, Formosa Province, Argentina.

Habitat. The flatworms were found on the ground under fallen logs and palm leaves in environments with native vegetation.

Etymology. The specific name derives from the language of Toba indigenous people that inhabit the Chacoan region; naweI means black, which refers to the colour of the dorsal surface of this species.

\section{Description}

\section{External morphology}

The body is elongated with parallel margins. In live specimens, the anterior end is pointed, becoming rounded after fixation. The posterior end narrows abruptly, ending sharp-edged. The colour pattern of the dorsal surface of live specimens is black (Fig. 1). The ventral surface is dark grey with a whitish and thin median longitudinal line along the body (Fig. 2a), which becomes weaker behind the gonopore. The eyes, with small clear halos, surround the anterior tip uniserially in an irregular row, and they extend toward both body margins for $2-5 \mathrm{~mm}$ in two and three longitudinal rows. Further back, they spread to both sides of the dorsal surface, forming various rows (15-20) at the end of the first third of body. At the level of the pharynx, the eyes are still dorsal (6-8 rows of eyes). They become less numerous in the copulatory apparatus region, and a few reach the posterior end (Fig. 2b).

After fixation, body length of the specimens ranged between 19 and $42 \mathrm{~mm}$. The maximum width was $2.4-8.3 \mathrm{~mm}$ and maximum height $1.2-2.4 \mathrm{~mm}$. The mouth was located at a distance of 54-62 \% from the anterior tip and the gonopore at 69-79\% (Table 1).

\section{Internal morphology \\ Cephalic region}

There are no musculo-glandular specializations. The dorsal epidermis is ciliated from the anterior tip until 1.9-2.5 mm (Fig. 3a). The creeping sole on the ventral epidermis is narrow (30-40 \% of body width) and progressively widens

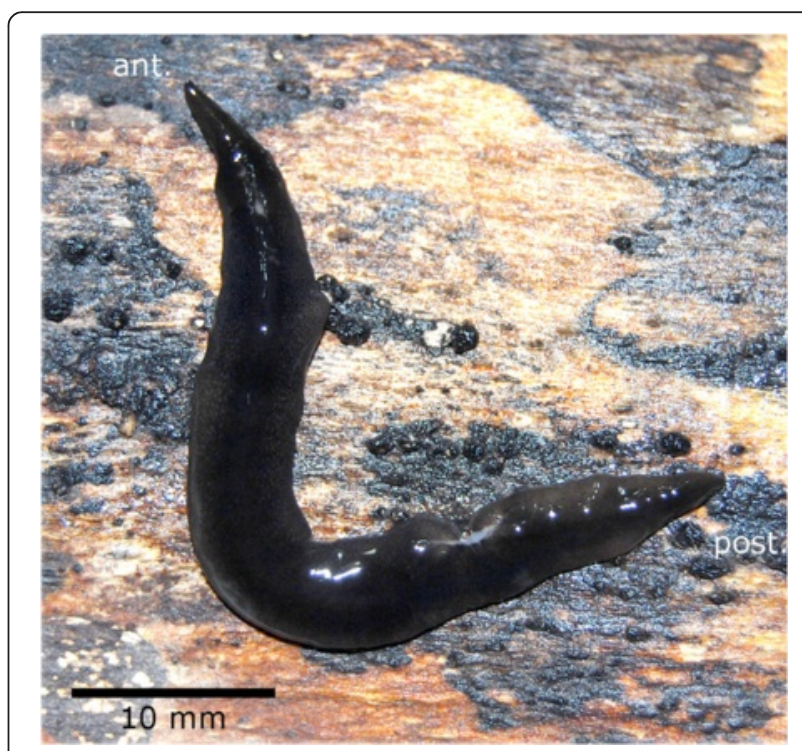

Fig. 1 Photograph of a live specimen of Notogynaphallia nawei sp. nov. (holotype). Dorsal view 


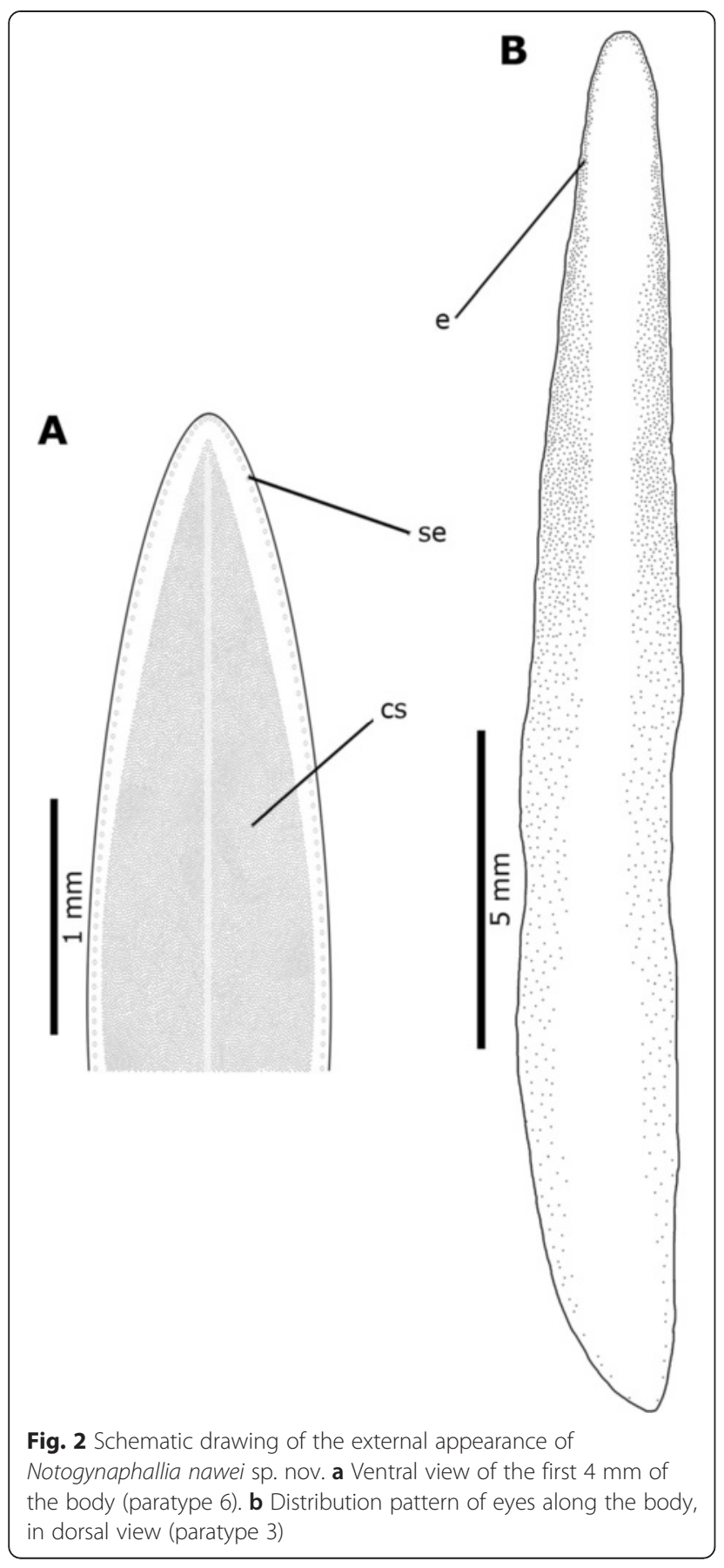

(Fig. 2a). The epidermis receives abundant secretions from xanthophil glands of two types (amorphous and fine granular secretions) and erythrophil and cyanophil glands with granular secretions. Also, rhabditogen secretions are abundant both in dorsal (rhammites) and ventral (small rhabdites) epidermis (Fig. 3a). Sensory pits, as simple invaginations (25-40 $\mu \mathrm{m}$ deep), surround the anterior tip (Fig. 3b, c). They spread along the ventral body margins in a single row forming the sensory border until $\sim 6 \mathrm{~mm}$ from the anterior tip (Fig. 2a).
The cutaneous musculature, consisting of the three typical layers of Geoplaninae (see below), exhibits the same arrangement at the pre-pharyngeal region, and its thickness relative to the body height (varying between 5 and $7 \%$ ) is similar to that of the pre-pharyngeal region. The parenchymatic musculature is ill-defined, being composed by intermingled fibres in the surrounding parenchyma.

\section{Epidermis and musculature at pre-pharyngeal region}

The dorsal epidermis is $20-40 \mu \mathrm{m}$ high, and ventrally, it is $25-40 \mu \mathrm{m}$ high. The ventral epidermis is ciliated on the creeping sole, which is approximately $90-95 \%$ of the body width (Fig. 2a, Table 1). Rhabditogen cell bodies are located in the parenchyma, below the cutaneous musculature (Fig. 3d). Their glandular secretions are abundant in the dorsal epidermis and the body margins (rhammites) and in the ventral epidermis partially occupy its height (small rhabdites) (Figs. 3d, e and 4). Numerous glands with fine and coarse granular erythrophil secretion and glands with fine granular and amorphous cyanophil secretion, whose cell bodies are located into the parenchyma, open through the entire epidermis. The creeping sole receives openings of abundant cells with erythrophil coarse granular secretion and cyanophil amorphous secretion and less numerous cells with erythrophil fine granular secretion and erythrophil amorphous secretion. There is no glandular margin.

The cutaneous musculature is composed of a subepithelial circular layer followed by a diagonal layer with decussate fibres and a longitudinal layer arranged in bundles. Cutaneous muscular index (CMI) varies between 3 and $7 \%$ (Table 2). The parenchymatic musculature is composed by ill-defined supra-intestinal and subintestinal transverse layers and dorso-ventral fibres located between the intestinal branches (Fig. 4). The thickness of the parenchymatic musculature (PMI) represents $1.5-2 \%$ of the body height (Table 2 ).

\section{Digestive system}

The pharynx (1.5-5.1 $\mathrm{mm}$ in length) is cylindrical, with the dorsal insertion posteriorly displaced $(0.5-1.1 \mathrm{~mm})$ (Fig. 5a-d). The mouth is located in the middle of the pharyngeal pouch (2.1-5.7 $\mathrm{mm}$ in length). The epithelial lining of the outer surface of the pharynx is cuboidal and ciliated. The outer pharyngeal musculature is arranged in a thin longitudinal subepithelial layer $(2.5-5 \mu \mathrm{m}$ thick) followed by a thicker circular layer (7.5-20 $\mu \mathrm{m}$ thick). The pharyngeal lumen is lined with a columnar and ciliated epithelium. The inner pharyngeal musculature consists of a thick layer of circular fibres $(85-200 \mu \mathrm{m}$ thick) and a subjacent longitudinal thin layer $(5-10 \mu \mathrm{m}$ thick). The pharynx receives secretion from abundant glands, the cell bodies of which are located both laterally 
Table 1 Measurements of external characters of Notogynaphallia nawei sp. nov. All the measurements (mm) were obtained from fixed specimens

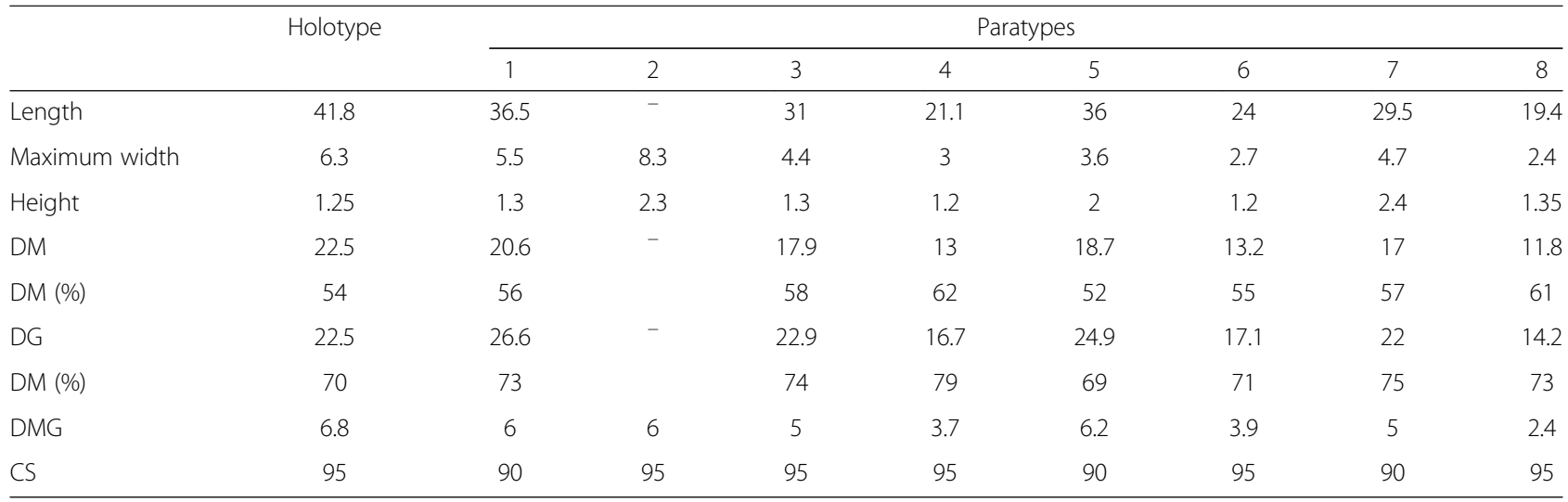

CS width of the creeping sole (\%), DG distance of gonopore from anterior end, DM distance of mouth from anterior end, DMG distance between mouth and gonopore

and anteriorly to the pharynx, and their cell necks extend to the pharyngeal epithelium. Four types of pharyngeal glands occur: abundant glands with (1) erythrophil, fine granules and (2) xanthophil amorphous secretion, as well as less numerous glands with (3) erythrophil and (4) cyanophil amorphous secretion. The oesophagus (150$350 \mu \mathrm{m}$ in length) is lined with a columnar and ciliated epithelium. Its subjacent musculature (40-125 $\mu \mathrm{m}$ thick) is continuous with the internal pharyngeal musculature, but it is thinner than the latter. The oesophagus:pharynx ratio varies from 5 to $10 \%$.

\section{Male reproductive system}

The testes are arranged in two or three irregular rows on each side of the body, situated dorsal to the intestinal branches and just below the supra-intestinal transverse parenchymatic layer (Figs. 3d and 4). They begin before the ovaries and extend to the pre-pharyngeal region, slightly before the pharyngeal root. They are located at a distance between $10-17 \%$ and $47-54 \%$ of the body length from the anterior end (Table 3). Sperm ducts run among the fibres of subintestinal parenchymatic muscle layer, located slightly dorsal, medially displaced, to ovovitelline ducts (Fig. 4). Their distal portions are expanded with their lumen full of spermatozoa. They bend slightly toward the dorsum and the sagittal plane, going through the common muscle coat, and open, close to each other, into the proximal portion of the prostatic vesicle (Fig. 6). The intrabulbar prostatic vesicle is composed by a tubular and sinuous proximal portion $(\sim 1 \mathrm{~mm}$ in length on average) followed by a globose part with narrow lumen (Figs. 6 and 7a). The prostatic vesicle broadly communicates with the male atrium. The ejaculatory duct is absent. The male atrium possesses richly folded walls, and thus, the communication with the female atrium occurs through a narrow lumen (Figs. 6 and 7a). The male atrium is longer than the female atrium (1.8 times on average).

Sperm ducts are lined with a ciliated squamous epithelium, and they are enveloped by a thin circular muscle layer $(2.5 \mu \mathrm{m}$ thick). The prostatic vesicle, both the sinuous portion as the globose one, is lined with a ciliated columnar epithelium traversed by erythrophil fine and coarse granular secretion and scarce erythrophil amorphous secretion arising from cell bodies located in the vicinity of the prostatic vesicle and in the surrounding parenchyma. These glandular secretions are more abundant and strongly stained in the globose portion (Fig. $7 \mathrm{a}-\mathrm{C}$ ). A thin muscular layer composed by interwoven circular, longitudinal and oblique fibres $(5-15 \mu \mathrm{m}$ thick) surround the prostatic vesicle. The male atrium is lined with a columnar epithelium, taller in the distal portion of the male atrium than in its proximal portion. The epithelium of the male atrium is only ciliated in its proximal portion, in the transition with the prostatic vesicle (Fig. 6). Its muscularis is composed by a thin subepithelial circular layer $(5-20 \mu \mathrm{m}$ thick) followed by a thicker longitudinal subjacent layer (15-40 $\mu \mathrm{m}$ thick) (Fig. 7d); it is thicker distally than proximally. The proximal part of the male atrium receives granular secretion from abundant cyanophil glands and less abundant erythrophil glands. The distal part receives openings from erythrophil glands with granular secretion and less abundant cyanophil glands with amorphous and coarse granular secretions. The cell bodies of these glands are located internally to the common muscle coat. The lumen of prostatic vesicle and male atrium of some specimens present spermatozoa. Around the male organs, the common muscular coat is mainly composed by longitudinal fibres, with some circular and oblique fibres, thicker dorsally (30-40 $\mu \mathrm{m}$ thick) than ventrally (20 $\mu \mathrm{m}$ thick). 


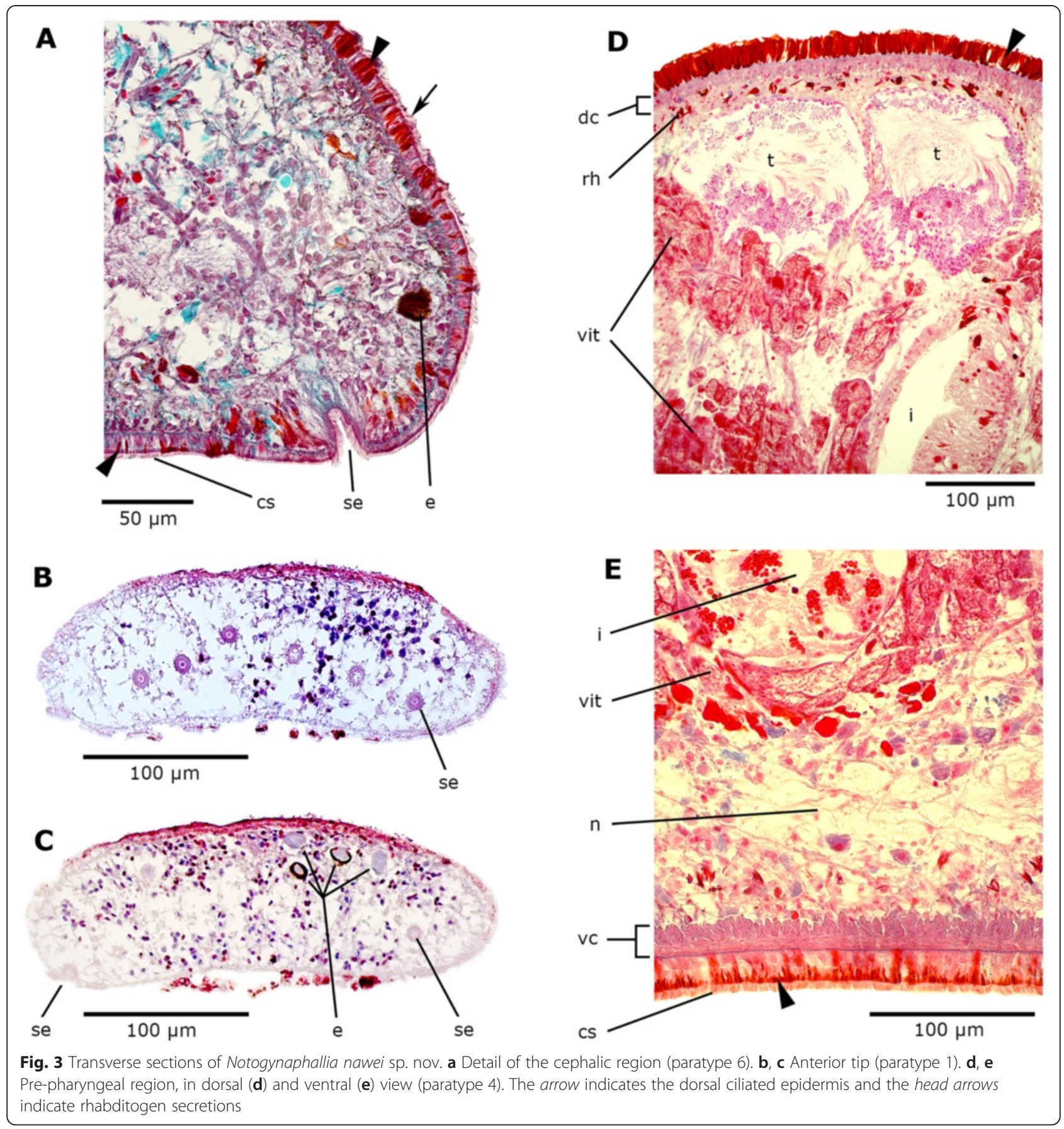

\section{Female reproductive system}

The ovaries are located at a distance of 15-22\% of the body length from the anterior end (Table 3 ). They are ventral, situated just below the intestine, and ovoid in shape (Fig. 7e). The ovovitelline ducts emerge dorsally from the middle of the ovaries and pass along their dorsal side. The proximal portions of the ovovitelline ducts are full of spermatozoa (Fig. 7e). The ovovitelline ducts run backward, and at the level of the proximal portion of the female atrium, they ascend almost vertically, bending a short track toward the sagittal plane to join above the female genital canal and form the common glandular ovovitelline duct (Fig. 6). The common glandular ovovitelline duct is short (100-200 $\mu \mathrm{m}$ in length) which, together with the female genital canal (100-300 $\mu \mathrm{m}$ in length), constitutes a "C" (Fig. 7f). The proximal portion of the female atrium is tubular, and its lumen progressively widens to form a cavity with scarcely folded walls (Figs. 6 and $7 \mathrm{a}, \mathrm{f}$ ). 


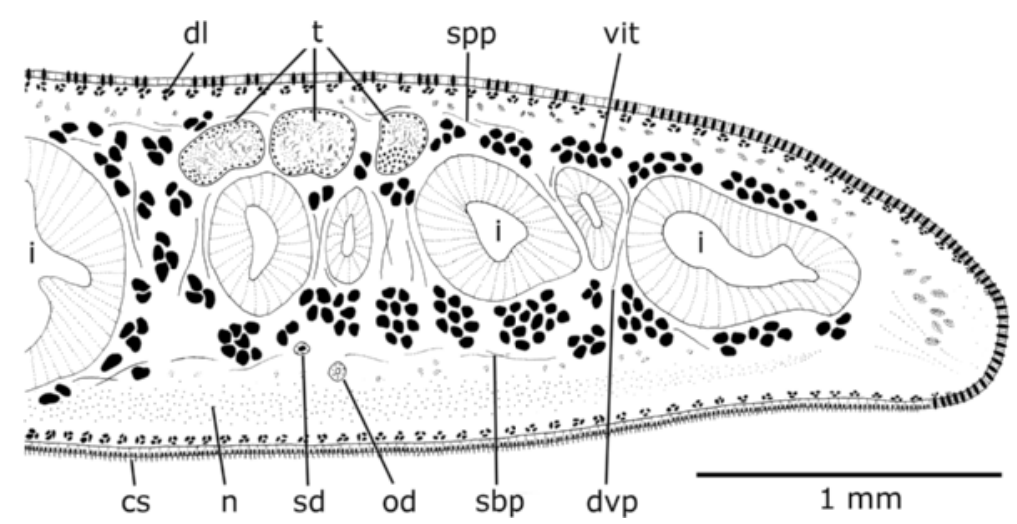

Fig. 4 Schematic drawing of a transversal section of the pre-pharyngeal region of Notogynaphallia nawei sp. nov. (holotype). For simplicity, only the cutaneous longitudinal muscle layer was drawn

The ovovitelline ducts are lined with a ciliated cuboidal epithelium, and they are enveloped by a circular muscle layer $(2.5-5 \mu \mathrm{m}$ thick). The distal ascending portions of the ovovitelline ducts receive scarce secretion of the shell glands. The lining epithelium of the common glandular ovovitelline duct is ciliated and columnar, receiving abundant secretion of the shell glands (Figs. 6 and 7f). The musculature of the common glandular ovovitelline duct is formed by intermingled circular and longitudinal fibres $(5-15 \mu \mathrm{m}$ thick). The female genital canal is lined with a ciliated columnar epithelium followed by a subjacent musculature composed by intermingled circular and longitudinal fibres (10-30 $\mu \mathrm{m}$ thick). The epithelium of the female genital canal receives erythrophil granular secretion and cyanophil amorphous secretion from glands located below the musculature. The female atrium is lined with a columnar epithelium, and the

Table 2 Measurements of the thickness of the musculature of Notogynaphallia nawei sp. nov.

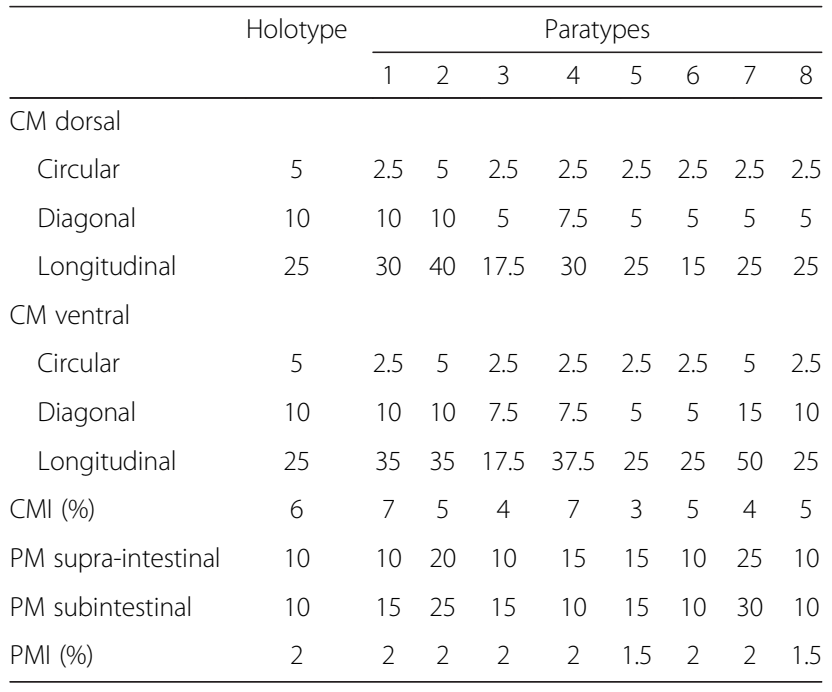

$C M$ cutaneous musculature $(\mu \mathrm{m}), P M$ parenchymatic musculature $(\mu \mathrm{m}), C M I$ cutaneous muscular index, $P M I$ parenchymatic muscular index subjacent muscularis is composed by two layers, a circular subepithelial (10-25 $\mu \mathrm{m}$ thick) and a longitudinal subjacent (15-40 $\mu \mathrm{m}$ thick). Abundant erythrophil granular secretion and scarce cyanophil amorphous secretion, from glands situated outward of its muscularis, open into the female atrium. Spermatozoa were observed in the lumen of the female genital canal and female atrium of the holotype (Fig. 7f) and in other specimens. Around the female organs, the common muscular coat is composed by intermingled fibres of longitudinal, circular and oblique orientation, thicker dorsally (30-40 $\mu$ m thick) than ventrally (15-20 $\mu \mathrm{m}$ thick).

Vitellaria are well developed and highly abundant along the body. In the anterior and pre-pharyngeal regions, vitellaria occupy the spaces between intestinal branches (Figs. 3d, e, 4 and 7e).

\section{Some comments about specimen fixation}

It is widely well known that a rapid fixation is necessary to preserve tissues and maintain its morphological features, minimizing the enzymatic destruction of cellular and extracellular molecules by autolysis processes and microorganisms (Bancroft and Gamble 2008). The fixatives sometimes produce some artefacts in the appearance of tissues. However, in the case of flatworms, another source of artefacts arises from the methodology used to kill them. Over the years, the use of boiling water as a method to rapidly killing land flatworms was established to minimize the contortion and rupture of these animals (Lincon and Sheals 1979; Winsor 1991). This procedure should be done when the specimen is creeping, with an extended body. As quickly as possible, the water should be replaced by the fixative (usually $10 \%$ formaldehyde), trying not to touch the specimen due to its stickiness. If this protocol is not properly followed (e.g. performing the fixation directly in aqueous formaldehyde), the animals sometimes do not die instantly, suffering contractions and distortions of the 


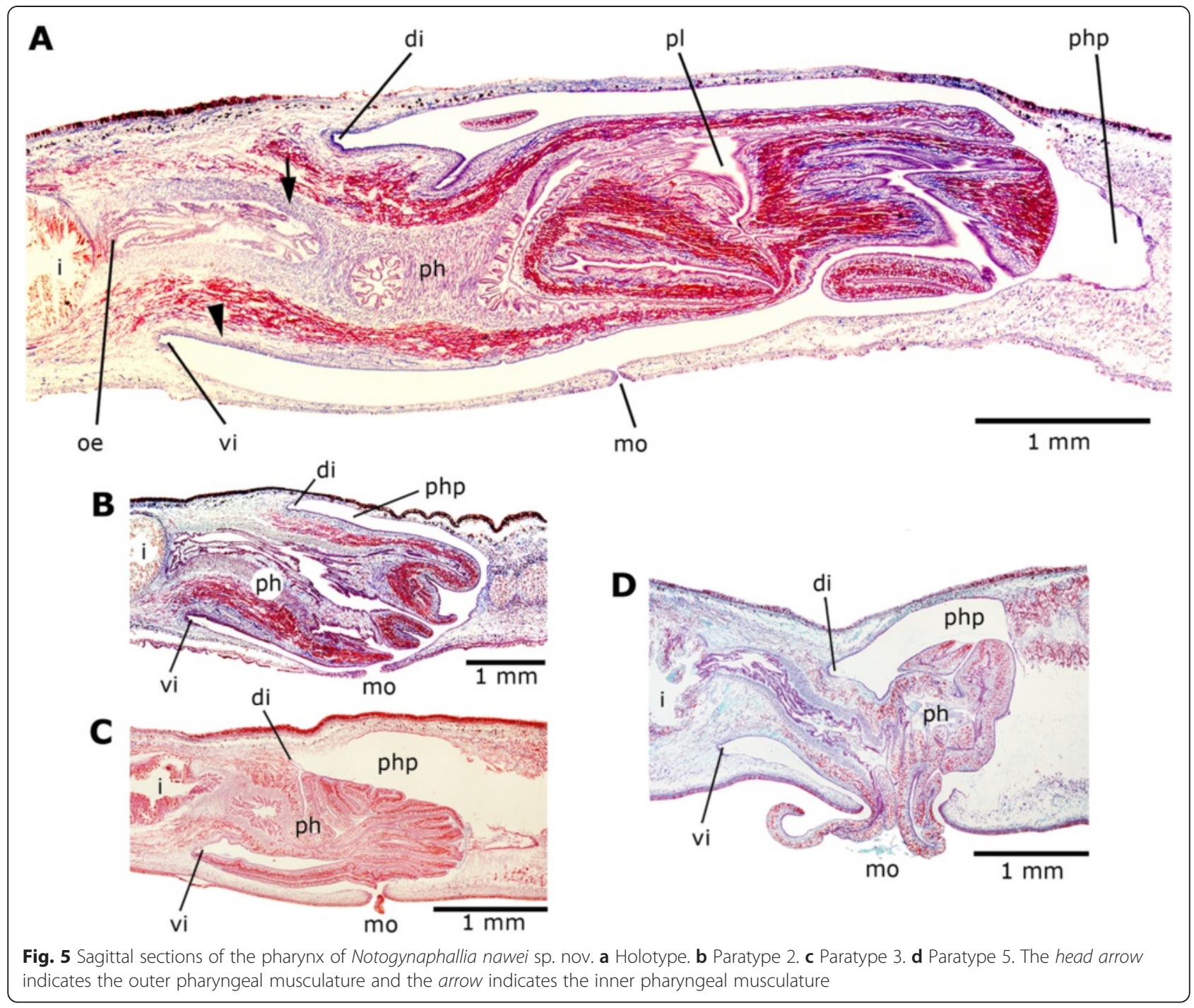

body (commonly with the pharynx and the penis papilla protruded) making it difficult its study or causing a misinterpretation of the anatomy.

The holotype of N. nawei sp. nov. shows no signs of contraction or distortion because it was properly fixed. The paratypes show artefacts since the method of rapidly killing them was not followed properly. Some comments mainly about variations in the morphology of the copulatory apparatus (compared to the holotype) could be helpful for comparison with other species that exhibit similar artefacts.

In paratype 1 , the distal portion of the sperm ducts has been contorted so that they ascend and open dorsally into the prostatic vesicle (Fig. 8a). With slight variations, in all specimens, the tubular portion of the prostatic vesicle maintains similar appearance to the holotype, but the distal globose portion shows alterations in its form, with the exception of paratype 3 (Fig. 8c). In paratype 1, the distal portion of the prostatic vesicle is poorly differentiated and somewhat contracted (Fig. 8a); in paratypes 2, 6 and 8, there are signs of contraction, and it is higher than longer (Fig. 8b, e and f), while in the paratype 5 it is longer than higher (Fig. 8d). However, all specimens show the same histological features observed in the holotype, distinguishing both regions of the prostatic vesicle according to their staining pattern with the globose portion more strongly stained than the tubular portion (Fig. $7 \mathrm{a}-\mathrm{c}$ ). The male atrium of paratypes shows contraction, evidenced by tighter folds than the holotype, resulting in a male atrium with narrower lumen, remarkably evident in paratype 1 (Fig. 8a).

Regarding the female atrium, some alterations were observed in comparison with the holotype. In paratypes $1,3,5$ and 8 , the atrium bent toward the dorsum and adopted an oblique position, while in paratypes 2 and 6 the female atrium suffered contraction, especially in the latter (Fig. 8). 
Table 3 Measurements of the reproductive system of Notogynaphallia nawei sp. nov.

\begin{tabular}{|c|c|c|c|c|c|c|c|c|c|}
\hline & \multirow[t]{2}{*}{ Holotype } & \multicolumn{8}{|c|}{ Paratypes } \\
\hline & & 1 & 2 & 3 & 4 & 5 & 6 & 7 & 8 \\
\hline \multirow[t]{2}{*}{ Anteriormost testes } & 5 & 6.2 & - & 5 & 3.3 & - & 2.5 & - & 2.6 \\
\hline & $(12 \%)$ & $(17 \%)$ & & $(16 \%)$ & $(16 \%)$ & & $(10 \%)$ & & $(13 \%)$ \\
\hline \multirow[t]{2}{*}{ Posteriormost testes } & 20.5 & 18.5 & - & 15.9 & 11.3 & 17.7 & 11.3 & 15.2 & 10.5 \\
\hline & $(49 \%)$ & $(51 \%)$ & & $(51 \%)$ & $(53 \%)$ & $(49 \%)$ & $(47 \%)$ & $(51 \%)$ & $(54 \%)$ \\
\hline LPV (proximal) & 1.2 & 1 & 1 & 0.85 & 0.95 & 1.2 & 0.8 & 0.8 & 0.85 \\
\hline LPV-HPV (distal) & $0.5-0.7$ & $0.15-0.25$ & $0.4-0.9$ & $0.4-0.5$ & $0.5-0.7$ & $0.7-0.4$ & $0.4-0.6$ & $0.15-0.25$ & $0.15-0.5$ \\
\hline LMA & 2.2 & 1.4 & 2.1 & 1.2 & 1.4 & 1.7 & 1.2 & 1.1 & 1.1 \\
\hline \multirow[t]{2}{*}{ Ovaries } & 7.2 & 7.3 & - & 6.4 & 4.9 & - & 3.6 & - & 4.2 \\
\hline & $(17 \%)$ & $(20 \%)$ & & $(21 \%)$ & $(21 \%)$ & & $(15 \%)$ & & $(22 \%)$ \\
\hline LCGD & 0.15 & 0.15 & 0.2 & 0.125 & 0.125 & 0.2 & 0.1 & 0.1 & 0.1 \\
\hline LFG & 0.125 & 0.15 & 0.2 & 0.2 & 0.25 & 0.3 & 0.1 & 0.15 & 0.1 \\
\hline LFA & 1.35 & 0.8 & 0.9 & 0.65 & 0.8 & 0.65 & 0.6 & 0.8 & 0.75 \\
\hline
\end{tabular}

The numbers given in parentheses represent the position relative to body length

HPV height of prostatic vesicle, $L C G D$ length of common glandular ovovitelline duct, $L F A$ length of female atrium, $L F G$ length of female genital canal, $L M A$ length of male atrium, LPV length of prostatic vesicle, $T: B H$ ratio of the height of testes to the height of the body

Additional evidence of artefacts was observed in the pharynx. Although in the holotype there is no evidence of contraction or distortion (Fig. 5a), the pharynx of the remaining specimens suffered some contraction (Fig. $5 \mathrm{~b}, \mathrm{c})$. In paratype 5 , the pharynx was slightly protruded and contracted, with a distortion of the pharyngeal pouch (Fig. 5d).

\section{Discussion}

General comments on the genus Notogynaphallia and on its emended diagnosis

After a phylogenetic analysis of the subfamily Geoplaninae based on molecular data, Carbayo et al. (2013) proposed to restrict the genus to six species of the group originally proposed by Ogren and Kawakatsu (1990), i.e., Notogynaphallia sexstriata (Graff, 1899), Notogynaphallia modesta (Graff, 1899), Notogynaphallia mourei (C.G. Froehlich, 1956) Notogynaphallia parca (E.M. Froehlich, 1955), Notogynaphallia plumbea (C.G. Froehlich, 1956) and Notogynaphallia froehlichae Ogren \& Kawakatsu, 1990. Carbayo et al. (2013) also proposed the inclusion of Geoplana biseminalis Riester, 1938 into this group. Four other species were considered to be morphologically not well known (Notogynaphallia incertae sedis), namely Notogynaphallia atra (Schultze \& Müller, 1857), Notogynaphallia garua (Du Bois-Reymond Marcus, 1951), Notogynaphallia quinquestriata (Hyman, 1962) and Notogynaphallia andina (Hyman, 1962). From the seven remaining species in Notogynaphallia, three were analysed by Carbayo et al. (2013)

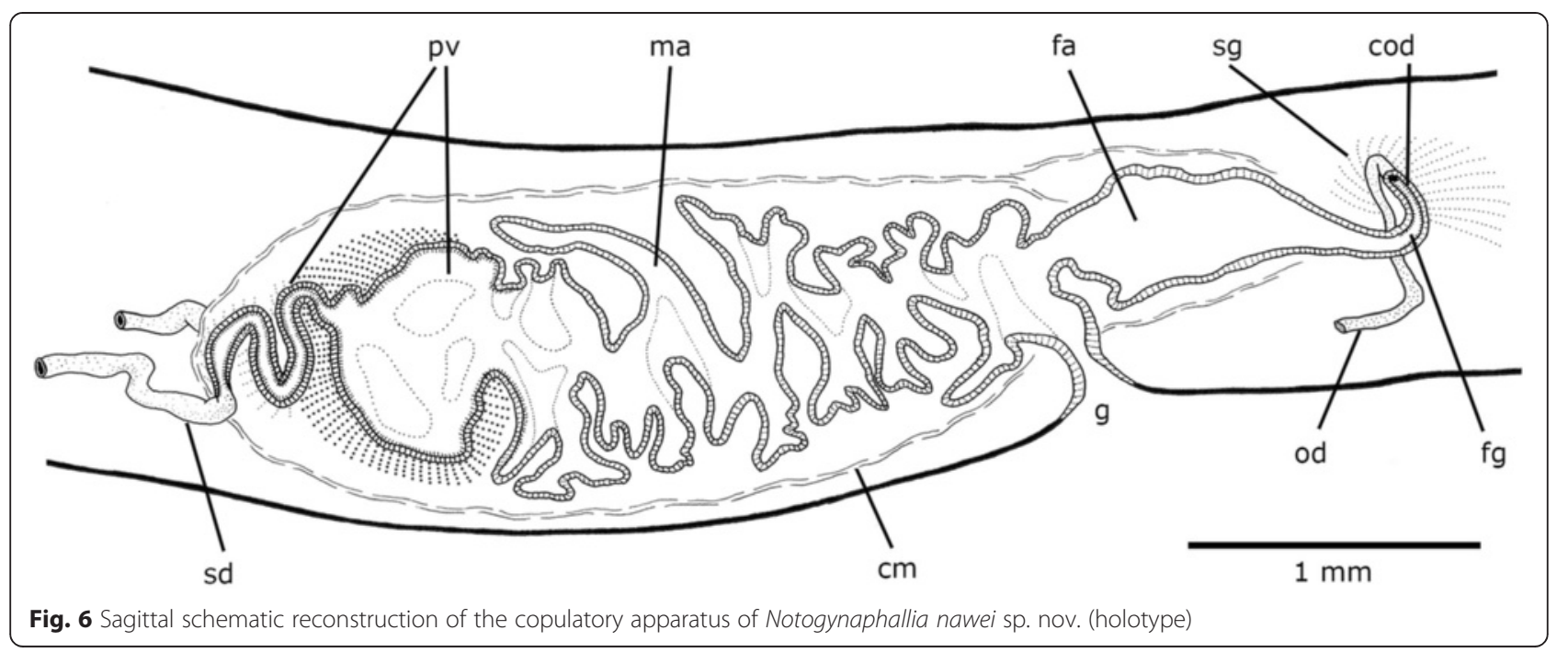




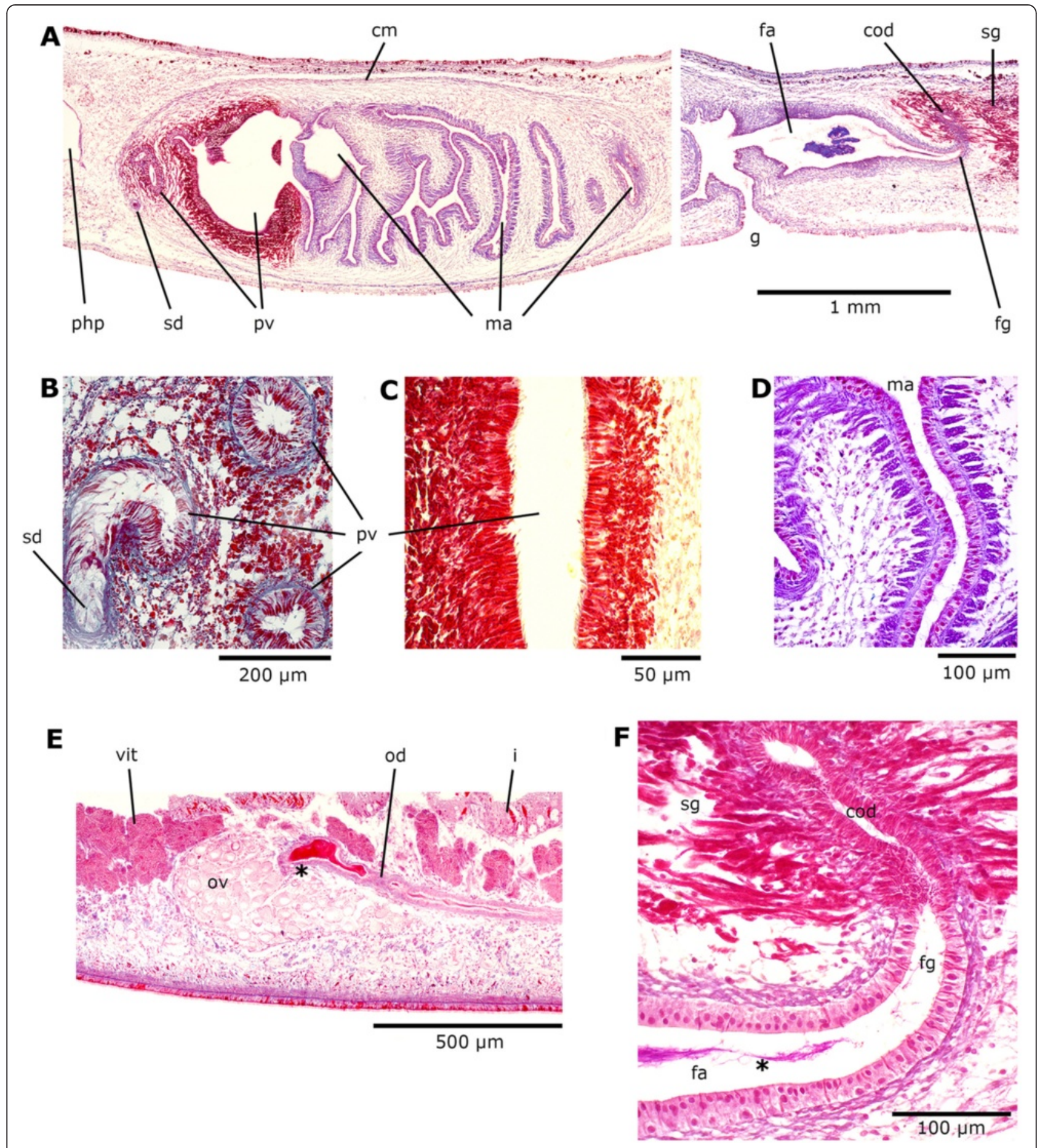

Fig. 7 Sagittal sections of the reproductive system of Notogynaphallia nawei sp. nov. a Copulatory apparatus (holotype). b Proximal portion of the prostatic vesicle (paratype 5). c Distal portion of the prostatic vesicle (paratype 4). d Male atrium (holotype). e Ovary (paratype 3). $\mathbf{f}$ Detail of the female reproductive system (holotype). $\left(^{*}\right)$ spermatozoa

in the molecular phylogeny of Geoplaninae. Although it is not the aim of the present paper to make a revision of Notogynaphallia, our comparison of the new species with the other species of the genus indicated the need of some comments on the whole genus and a proposal for altering its generic diagnosis.

Regarding the external morphology, there are species of Notogynaphallia with four to six stripes over the dorsum, 

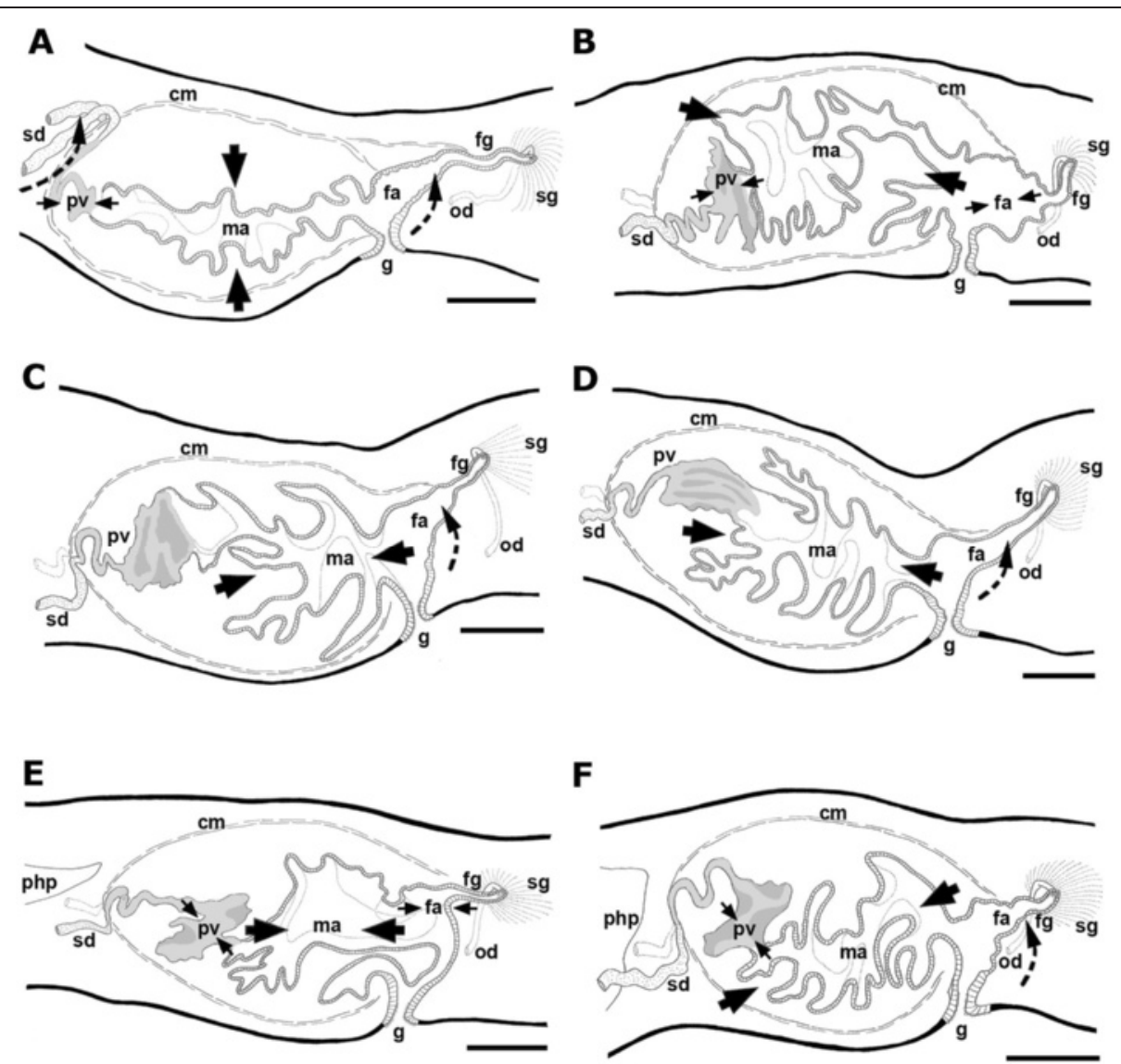

Fig. 8 Sagittal schematic reconstruction of the copulatory apparatus of some specimens of Notogynaphallia nawei sp. nov. with tissue distortions. Scale bars: $500 \mu \mathrm{m}$. a Paratype 1. b Paratype 2. c Paratype 3. d Paratype 5. e Paratype 6. f Paratype 8. Dashed arrows indicate the direction of dislocation of the sperm ducts and female reproductive system; small arrows indicate the direction of contraction of the prostatic vesicle (distal portion) and female atrium; big arrows indicate the direction of contraction of the male atrium

such as $N$. modesta, $N$. sexstriata and $N$. froehlichae (Graff 1899; Riester 1938), or with two broad lateral bands over the dorsum ( $N$. mourei and N. parca) (Froehlich 1955b; Froehlich, 1956). N. modesta shows a brown pigmented dorsum with two darker medial as well as two lateral stripes (Graff 1899), whereas N. sexstriata and $N$. froehlichae have dark stripes over a yellowish ground. The type species, $N$. plumbea, has a homogeneous dorsal pattern (Froehlich 1956). From Notogynaphallia biseminalis, known just by a body fragment at the level of the copulatory apparatus of a single specimen (Riester 1938), there is no information about its general external morphology.

In relation to eye pattern, most species of Notogynaphallia have exclusively marginal eyes, but $N$. modesta and $N$. froehlichae have eyes spreading over the dorsum (Riester 1938; Carbayo 2003). Thus, we propose to modify the generic diagnosis to include the variation in eye pattern in species of the group.

Regarding pharyngeal morphology, most species of the genus present a cylindrical pharynx, but $N$. modesta has a cylindrical to bell-shaped pharynx (Carbayo 2003). In addition, at least $N$. parca has a cylindrical pharynx with a dorsal insertion shifted posteriorly. In fact, there is just a slight difference between a cylindrical pharynx with a dorsal insertion shifted posteriorly and a bell-shaped pharynx. Therefore, in view of these arguments, we propose an alteration to the generic diagnosis to consider this variation in the pharyngeal morphology.

In relation to the copulatory apparatus, all species of Notogynaphallia share a compact copulatory apparatus with a highly folded male atrium, which probably forms a temporary penis papilla during copulation. Such an eversible penis is characterized by strong atrial musculature (Winsor 1998). Also, the prostatic vesicle, exclusively intrabulbar, opens broadly into the male atrium, without an ejaculatory duct. Furthermore, in species of Notogynaphallia, the ascending portion of the female ducts is lateral to the posterior region of the female atrium and joins each other behind it. The genital canal, arising from the posterior region of the female atrium, is dorso-anteriorly flexed (Carbayo et al. 2013). Among species of the genus, some 
variation is observed in the prostatic vesicle, which can be globose (N. mourei, N. parca, N. plumbea and N. sexstriata) or tubular (N. biseminalis, N. froehlichae and $N$. modesta), and may have two different regions, as occurs in N. modesta (Carbayo 2003). In addition, adenodactyls or glandulo-muscular organs have not been observed according to the original descriptions (Graff 1899; Riester 1938; Froehlich 1955b; Froehlich 1956).

From the four species which were considered as Notogynaphallia incertae sedis, $N$. atra has an almost homogeneous coloured dorsum (Froehlich 1956), whereas $N$. garua, $N$. andina and $N$. quinquestriata have a striped dorsal surface (Du Bois-Reymond Marcus 1951; Hyman 1962). Eyes spread over the dorsal surface in $N$. atra, $N$. garua and $N$. andina. The pharynx is cylindrical in $N$. garua, $N$. quinquestriata and $N$. andina (Du BoisReymond Marcus 1951; Hyman 1962; Carbayo 2003) and seems to vary from cylindrical to bell-shaped in $N$. atra (Froehlich 1956; Carbayo 2003). Two of these species, $N$. atra and $N$. andina, have some peculiarities in their genital anatomy in relation to other species of the genus, as already commented by Froehlich and Leal-Zanchet (2003). The genital anatomy is unknown in $N$. quinquestriata, since the single studied specimen was in an initial stage of maturation (Hyman 1962; Carbayo 2003). N. garua has a general genital anatomy similar to that of other species of the genus, but their type specimens were not fully mature (Du Bois-Reymond Marcus 1951; Carbayo 2003).

It should be noted that other additional characteristics need to be considered for inclusion in the diagnosis of the genus, namely the cutaneous and parenchymatic musculatures in the anterior and pre-pharyngeal body regions. These musculatures provide diagnostic characters at the genus level (Froehlich 1955a; Carbayo and Leal-Zanchet 2003); thus, it is justified to make some comments. According to Carbayo (2003), the type species of the genus, $N$. plumbea, together with $N$. froehlichae, $N$. modesta, N. mourei, N. parca and N. sexstriata have the usual tripartite cutaneous musculature of Geoplaninae in the pre-pharyngeal region. The arrangement of the cutaneous muscle layers remains the same toward the anterior region, without cephalic specializations, and the cutaneous musculature is not sunk into the parenchyma in the species that constitute the genus Notogynaphallia sensu Carbayo et al. (2013). In N. froehlichae, however, the cutaneous musculature of the anterior body region is unknown because the holotype is damaged. Carbayo (2003) also indicated for N. modesta, N. mourei, N. parca, $N$. plumbea and $N$. sexstriata that the parenchymatic musculature is composed of three main layers: a dorsal diagonal with decussate fibres and two layers with transverse fibres, namely a supra-intestinal and a subintestinal.
In $N$. froehlichae, only the dorsal diagonal and supraintestinal parenchymatic muscle layers have been observed. Parenchymatic longitudinal fibres are absent in species of Notogynaphallia sensu Carbayo et al. (2013) with the exception of $N$. sexstriata, in which loose longitudinal fibres intermingled with the subintestinal parenchymatic layer were observed (Carbayo 2003). For $N$. biseminalis, the arrangement of both the cutaneous and parenchymatic muscle layers is unknown (Riester 1938). Thus, the diverse characteristics which were observed in the parenchymal musculatures of $N$. froehlichae and $N$. sexstriata should be profoundly addressed, as well as the description of the cutaneous and parenchymatic musculatures of $N$. biseminalis. These actions should be taken in the light of a phylogenetic analysis, improving the definition of the genus.

\section{Comparative discussion of $N$. nawei sp. nov. in the genus Notogynaphallia}

Specimens of $N$. nawei sp. nov. have a medium-sized, elongated body with parallel margins, similarly to other species of the genus. The new species shows eyes spreading over the dorsal surface, similarly to $N$. froehlichae and $N$. modesta. Regarding pharyngeal anatomy, $N$. nawei is similar to most species of the genus, presenting a cylindrical pharynx. Considering that these features of the external morphology and pharyngeal anatomy can also occur in other genera of Geoplaninae, we found in its genital anatomy the main reasons to propose the inclusion of the new species into the genus Notogynaphallia, namely an intrabulbar prostatic vesicle broadly communicated with the folded male atrium, an eversible penis, female ducts lateral to the posterior region of the female atrium and joining each other behind it and a dorsoanteriorly flexed female genital canal, arising from the posterior region of the female atrium. In relation to the colour pattern, $N$. nawei sp. nov., with a homogeneous and dark dorsal surface, can be distinguished from the majority of its congeners ( $N$. froehlichae, $N$. modesta, $N$. mourei, $N$. parca and $N$. sexstriata) and resembles $N$. plumbea. Notogynaphallia plumbea exhibits a dark grey to dark brown pigmentation on the back and greyish ventral surface. However, no clear halos occur surrounding the eyes, which are situated only along body margins (Froehlich 1956; Carbayo 2003). In the new species, the eyes extend toward the dorsal surface and present small clear halos that are better distinguished in live specimens. In addition, regarding genital anatomy, the prostatic vesicle is ovoid in N. plumbea (Froehlich 1956; Carbayo 2003), whereas in $N$. nawei sp. nov. it has a proximal tubular portion, absent in N. plumbea.

Although the external aspect of $N$. modesta differs from that of the new species, the copulatory apparatus of $N$. nawei sp. nov. resembles $N$. modesta since in both 
species the sperm ducts pass through the common muscular coat and immediately open into an intrabulbar prostatic vesicle, which anatomically and histologically is differentiated in two portions: tubular and sinuous proximally and globose with folded walls distally. However, in N. modesta, sperm ducts join each other at the point where they traverse the common muscle coat, thus being a single opening in the prostatic vesicle, while in the new species sperm ducts open into the proximal portion of the prostatic vesicle close to each other, but without forming a common portion. In both species, the male atrium is richly folded, but in $N$. modesta, the folds are almost restricted to the ventral wall, while in $N$. nawei sp. nov. they occur both dorsally and ventrally. Both species also share the morphology of the common glandular ovovitelline duct and the female genital canal, being C-shaped.

Regarding the species of Notogynaphallia incertae sedis, $N$. nawei sp. nov. can be distinguished from the striped specimens of $N$. andina, $N$. quinquestriata and $N$. garua. The dorsal pattern of $N$. nawei sp. nov. is similar to that of $N$. atra, which has a black pigmentation on the back and greyish ventral surface. However, N. atra has a bell-shaped pharynx, according to Carbayo (2003), and the male reproductive system presents an extrabulbar, ovoid and vertically disposed prostatic vesicle (Froehlich 1956; Carbayo 2003) and testes extending behind the pharynx (Carbayo 2003). Thus, N. nawei sp. nov., having a cylindrical pharynx, an intrabulbar and tubular prostatic vesicle and pre-pharyngeal testes, can be easily distinguished from $N$. atra.

In summary, $N$. nawei sp. nov. can be differentiated from other species of Notogynaphallia by the following combination of characters: homogeneous coloured dorsum, eyes spreading over the dorsal surface of the body, intrabulbar prostatic vesicle with two distinct portions and common glandular ovovitelline duct and female genital canal constituting a "C".

\section{Conclusions}

Considering the known distribution of the genus Notogynaphallia mainly in southern Brazil, besides the occurrence of species of Notogynaphallia incertae sedis in Colombia, Panama and Peru, the finding of a new species of Notogynaphallia for the first time in the Chacoan province in Argentina extends the distribution range of the genus. In addition, the present work increases the knowledge of the morphology of the genus, proposing an emendation to its diagnosis.

\section{Abbreviations}

cm: common muscular coat; cod: common glandular ovovitelline duct; cs: creeping sole; dc: dorsal cutaneous musculature; di: dorsal insertion; dl: dorsal cutaneous longitudinal musculature; dvp: dorso-ventral parenchymatic musculature; e: eyes; fa: female atrium; fg: female genital canal; g: gonopore; i: intestine; ma: male atrium; mo: mouth; n: nervous plate; od: ovovitelline duct; oe: oesophagus; ov: ovary; ph: pharynx; php: pharyngeal pouch; pl: pharyngeal lumen; pv: prostatic vesicle; rh: rhabditogen cells; sbp: subintestinal parenchymatic musculature; sd: sperm duct; se: sensory pits; sg: shell glands; spp: supra-intestinal parenchymatic musculature; t: testes; vc: ventral cutaneous musculature; vi: ventral insertion; vit: vitellaria.

\section{Competing interests}

The authors declare that they have no competing interests.

\section{Authors' contributions}

LN sampled part of the specimens, made part of the histological preparations, performed morphological analyses and figures and drafted the manuscript. FB sampled part of the specimens, conceived the study, participated in its design and helped to draft the manuscript. AMLZ participated in the design of the study and helped to draft the manuscript. All authors contributed to the specific identification of the new taxon, as well as read and approved the final manuscript.

\section{Acknowledgements}

We are grateful to colleagues Fabiana Drago and Lía Lunaschi for collecting some specimens. Rafaella Canelo and Letícia Guterres (laboratory technicians of the Instituto de Pesquisas de Planárias, Universidade do Vale do Rio dos Sinos, Brasil) are acknowledged for carrying out histological preparations of part of the material studied. We thank MSc. Edward Benya for the English review of the manuscript. LN and FB were financed by PIP 112-20120100635 CONICET (Consejo Nacional de Investigaciones Científicas y Técnicas), Agencia Nacional de Promoción Científica y Tecnológica (FONCyT) PICT 2007-01287 and UNLP (Universidad Nacional de La Plata) 11/N728. AMLZ was financed by the Brazilian Research Council (CNPq), under grants 477712/ 2006-1 and 143379/2009-7, and the Fundação de Amparo à Pesquisa do Rio Grande do Sul (FAPERGS). This work was partially financed by Ministerio de Ciencia, Tecnología e Innovación Productiva, Argentina and Coordenação de Aperfeiçoamento de Pessoal de Nível Superior, Brazil (MINCYT/CAPES 202/2012)

The authors would like to thank two anonymous reviewers for their valuable comments and suggestions, which were helpful for preparing the final version of the manuscript.

\section{Author details}

'División Zoología Invertebrados, Facultad de Ciencias Naturales y Museo, Universidad Nacional de La Plata, Boulevard 120 and 61, La Plata, Argentina. ${ }^{2}$ Instituto de Pesquisas de Planárias, Universidade do Vale do Rio dos Sinos, 93022-000 São Leopoldo, Rio Grande do Sul, Brazil. ${ }^{3}$ Instituto de Pesquisas de Planárias and Programa de Pós-Graduação em Biologia, Universidade do Vale do Rio dos Sinos, 93022-000 São Leopoldo, Rio Grande do Sul, Brazil.

Received: 22 December 2014 Accepted: 7 August 2015

Published online: 25 August 2015

\section{References}

Bancroft JD, Gamble M (2008) Theory and practice of histological techniques, 6th edn. Churchill Livingston Elsevier, Philadelphia

Carbayo F (2003) Revisión de Notogynaphallia Ogren \& Kawakatsu, 1990 (Platyhelminthes: Tricladidda). Universidad de Salamanca, PhD Tesis

Carbayo F (2010) A new genus for seven Brazilian land planarian species, split off from Notogynaphallia (Platyhelminthes, Tricladida). Belg J Zool 140:91-101

Carbayo F, Leal-Zanchet AM (2003) Two new genera of geoplaninid land planarians (Platyhelminthes: Tricladida: Terricola) of Brazil in the light of cephalic specialisations. Invert Syst 17:449-468. doi:10.1071/IT01035

Carbayo F, Álvarez-Presas M, Olivares CT, Marques FPL, Froehlich EM, Riutort M (2013) Molecular phylogeny of Geoplaninae (Platyhelminthes) challenges current classification: proposal of taxonomic actions. Zool Scr 42:508-528. doi:10.1111/zsc.12019

Du Bois-Reymond ME (1951) On South American geoplanids. Bol Fac Fil Ci Letr São Paulo, Zoologia 16:217-255

Froehlich CG (1955a) Sôbre morfologia e taxonomia das Geoplanidae. Bol Fac Fil Ci Letr São Paulo, Zoologia 19:195-279

Froehlich CG (1956) Planárias terrestres do Paraná. Dusenia 7:173-191 
Froehlich EM (1955b) Sôbre espécies brasileiras do gênero Geoplana. Bol Fac Fil Ci Letr São Paulo, Zoologia 19:289-369

Froehlich EM, Leal-Zanchet AM (2003) A new species of terrestrial planarian of the genus Notogynaphallia Ogren \& Kawakatsu (Platyhelminthes, Tricladida, Terricola) from south Brazil and some comments on the genus. Rev Bras Zool 20:745-753

Graff L (1894) Landplanarien. Viaggio del Dott. Alfredo Borelli nella Republica Argentina e Paraguay, V. Boll Mus Zool Anat Comp Torino 9:1-4

Graff L (1899) Monographie der Turbellarien: II. Tricladida Terricola (landplanarien). Verlag von Wilhelm Engelmann, Leipzig

Hyman LH (1962) Some land planarians from Caribbean countries. Am Mus Novit 2110:1-25

Kawaguti S (1932) On the physiology of land planarians III. The problems of desiccation. Mem Fac Sci Agric Taihoku Imp Univ 7:39-55

Leal-Zanchet AM, Froehlich EM (2001) A species complex in the genus Notogynaphallia (Platyhelminthes, Tricladida, Terricola). Belg J Zool 131:225-226

Leal-Zanchet AM, Froehlich EM (2006) A species complex in the genus Notogynaphallia Ogren \& Kawakatsu (Platyhelminthes: Tricladida: Terricola) with a taxonomic revision of homonyms of Geoplana marginata Schultze \& Müller and a reinterpretation of Notogynaphallia caissara (Froehlich) anatomy. Belg J Zool 136:81-100

Lincon RJ, Sheals JG (1979) Invertebrate animals. Collection and preservation. British Museum (Natural History). Cambridge University Press, London

Morrone JJ (2000) What is the Chacoan subregion? Neotropica 46:51-68

Morrone JJ (2014) Biogeographical regionalisation of the Neotropical region. Zootaxa 3782:1-110, doi:10.11646/zootaxa.3782.1.1

Negrete L, Brusa F (2012) Choeradoplana crassiphalla sp. nov. (Platyhelminthes: Tricladida: Geoplanidae): a new species of land planarian from the Atlantic Forest of Argentina. Stud Neotrop Fauna Environ 47:227-237. doi:10.1080/01650521.2012.735071

Negrete L, Colpo KD, Brusa F (2014a) Land planarian assemblages in protected areas of the Interior Atlantic Forest: implications for conservation. PLoS ONE 9, e90513. doi:10.1371/journal.pone.0090513

Negrete L, Leal-Zanchet AM, Brusa F (2014b) A new species of Supramontana Carbayo \& Leal-Zanchet (Platyhelminthes, Continenticola, Geoplanidae) from the Interior Atlantic Forest. Zootaxa 3753:177-186, doi:10.11646/zootaxa.3753.2.7

Ogren RE, Kawakatsu M (1990) Index to the species of the family Geoplanidae (Turbellaria, Tricladida, Terricola) Part I: Geoplaninae. Bull Fuji Women's Coll 28:79-166

Prasniski MET, Leal-Zanchet AM (2009) Predatory behavior of the land flatworm Notogynaphallia abundans (Platyhelminthes: Tricladida). Zoologia 26:606-612. doi:10.1590/S1984-46702009005000011

Riester A (1938) Beiträge zur Geoplaniden-Fauna Brasiliens. Abh Senckenberg Naturf Ges 441:1-88

Sluys R (1998) Land planarians (Platyhelminthes, Tricladida, Terricola) in biodiversity and conservation studies. Pedobiologia 42:490-494

Tyler S, Schilling S, Hooge M, Bush LF (comp.) (2006-2015) Turbellarian taxonomic database. Version 1.8. http://turbellaria.umaine.edu. Acceded 9 March 2015

Winsor L (1983) A revision of the cosmopolitan land planarian Bipalium kewense Moseley, 1878 (Turbellaria: Tricladida: Terricola). Zool J Linn Soc 79:61-100. doi:10.1111/j.1096-3642.1983.tb01161.x

Winsor L (1991) Methods for taxonomic and distributional studies of terrestrial flatworms (Tricladida: Terricola). Hydrobiologia 227:349-352. doi:10.1007/BF00027621

Winsor L (1998) Aspects of taxonomy and functional histology in terrestrial flatworms (Tricladida: Terricola). Pedobiologia 42:412-432

Submit your manuscript to a SpringerOpen ${ }^{\circledR}$ journal and benefit from:

- Convenient online submission

- Rigorous peer review

- Immediate publication on acceptance

- Open access: articles freely available online

- High visibility within the field

- Retaining the copyright to your article

Submit your next manuscript at $\gg$ springeropen.com 